\title{
Gastroprotective effects of methanol extract of Eremomastax speciosa leaf harvested in Southern part of Nigeria in rat
}

\author{
Samuel O. Onoja ${ }^{1 \star}$, Osborn Chinagorom ${ }^{1}$, Chinyere B. C. Ikpa ${ }^{2}$, Kelechi G. Madubuike ${ }^{1}$, \\ Ihechiluru I. Ezeigbo ${ }^{1}$, Solomon N. Ijioma ${ }^{1}$, Aruh O. Anaga ${ }^{3}$ and Maxwell I. Ezeja ${ }^{1}$
}

\begin{abstract}
Gastric ulcer is one of the common cause of hospital consultation with an increasing prevalence worldwide and it is traditionally managed with herbal medicine in the developing countries. This study investigated the gastroprotective effects of methanol extract of Eremomastax speciosa leaf in rats. Cold maceration in $80 \%$ methanol was adopted during extract preparation while gas chromatography mass spectroscopy (GC-MS) was employed in the phytochemical analysis. The doses of 25, 50 and 100 $\mathrm{mg} / \mathrm{kg}$ E. speciosa were used on ethanol-and indomethacin-induced gastric ulcer models in rats. The shay rat method was used to determine the effects of ESE on gastric acidity while the anticholinergic and antihistaminic activities were investigated on isolated rabbit jejunum ex vivo. The GC-MS analysis identified six bioactive compounds. Both ESE and cimetidine significantly $(\mathrm{p}<0.05)$ reduced the severity of indomethacin- and ethanol-induced gastric injuries and gastric acid contents in Shay rats. The extract elicited concentration-dependent relaxation of isolated rabbit jejunum and reduced the contraction induced by both acetylcholine and histamine in the same tissue. The findings showed that ESE protected the rats against chemical-induced gastric ulcer through anticholinergic and antihistaminic mechanisms.
\end{abstract}

Keywords: Acetylcholine, antiulcer, Eremomastax speciosa, histamine, indomethacin

'Department of Veterinary Physiology and Pharmacology, College of Veterinary Medicine, Michael Okpara University of Agriculture, PMB 7267, Umudike, Abia State, Nigeria

${ }^{2}$ Department of Chemistry, Imo State University P.M.B 2000, Owerri, Imo State Nigeria.

${ }^{3}$ Department of Veterinary Physiology and Pharmacology, Faculty of Veterinary Medicine, University of Nigeria Nsukka, Enugu State, Nigeria

*Corresponding author: S. O. Onoja E-mail: Onoja.samuel@mouau.edu.ng DOI: 10.2478/ebtj-2018-0050
(C) 2018 Authors. This work was licensed under the Creative Commons AttributionNonCommercial-NoDerivs 3.0 License.

\section{Introduction}

Gastric ulcer is one of the common cause of hospital consultation with an increasing prevalence worldwide (1-3). The increase in prevalence is attributed to indiscriminate use of non-steroidal anti-inflammatory drugs (NSAIDs), alcoholism, smoking and stress (4). The NSAIDs like Aspirin, inhibit cyclooxygenase (COX) activity and decrease prostaglandins production (5). Prostaglandin deficiency disrupts the normal protective mechanism that guard the gastric mucosa against ulceration (6-8). Asides neutrophil-dependent induced gastric ulcers by NSAIDs, other contributors to the pathology include cigarette smoking, alcohol consumption and Helicobacter pylori $(2,9)$. In clinical practice, gastric ulcer is usually treated with antacids, $\mathrm{H}_{2}$-receptor antagonists, prostaglandin analogues, proton pump inhibitors, and antibiotics (1). In developing countries about $80 \%$ of the populace explore medicinal herbs in the treatment of their ailment (10). Eremomastax speciosa is one of the herbs used in the treatment of stomach ulcer (11).

Eremomastax speciosa (Hochst) Cufod (Family Acanthaceae) normally grows as weed in the wild, although now cultivated for its medicinal properties in different parts of Africa (12), particularly in Akwa Ibom State, Nigeria $(13,14)$ and Anglophone Cameroun (15) . Eremomstax speciosa is polymorphous shrub with characteristic quadrangular stem and violet coloured leaves (11). It is widely used for its anti-anemic property (16) which has earned the plant, local names, such as "blood plant" or "pang nyemshe" by natives of Cameroun; "golden seal" or "African blood tonic plant;" in Nigeria, and "edem ididout" by the Ibibios 
in Akwa Ibom State, Nigeria (12). It is also used by the natives in the treatment of stomach pains (oral communiation). The anti-inflammatory, antioxidant, anti-nociceptive, anti-anemic, and anti-secretory activities of different parts of E. speciosa have been reported $(11,12,17,18)$. However, there is dearth of information on the gastroprotective abilities of leaf extract of E. speciosa harvested in Nigeria. Therefore, this study evaluated the gastroprotective effects of methanol extract of Eremomastax speciosa leaf harvested in Nigeria.

\section{Materials and Methods}

\section{Harvest and authentication of plant material}

The leaves of E. speciosa were harvested from Ikot-Ekwere Itam in Itu, Akwa-Ibom State, Nigeria and was identified by a botanist, Mr. Okon Etefia. A voucher sample was kept in the departmental herbarium with reference number MOUAU/ VPP/2015/15.

\section{Extract preparation}

The leaves were washed under running tap water, and then air dried on top of the laboratory bench. The dried and crispy plant leaves were pulverized into a coarse powder using a laboratory blender. The coarsely pulverized leaves of E. speciosa (500 g) were extracted by cold maceration in 80:20 methanol (Sigma Aldrich, Germany) in distilled water for $48 \mathrm{~h}$ at room temperature with intermittent agitations every $3 \mathrm{~h}$. Thereafter, the extract was filtered using Whatmann No. 1 filter paper and concentrated at $40^{\circ} \mathrm{C}$ in a hot air oven. The resulting extract was designated, Eremomastax speciosa extract (ESE) and stored in a refrigerator at $4^{\circ} \mathrm{C}$ until required.

\section{Gas chromatography-mass spectra (GC-MS) analysis}

Analysis was conducted using GC-MS (GCMS-QP2010 PLUS SHIMADZU, JAPAN) equipped with a DB-5MS column (30 m $\times 0.25 \mathrm{~mm}$ i.d., 0.25 um film thickness, J \& W Scientific, Folsom, $\mathrm{CA})$. The initial oven temperature was $60^{\circ} \mathrm{C}$. Helium at $1.0 \mathrm{~mL} /$ min was used as the carrier gas. The eluents were introduced directly into the MS through a transfer line maintained at $250^{\circ} \mathrm{C}$. The ionization voltage was $70 \mathrm{eV}$ and ion source temperature was $230{ }^{\circ} \mathrm{C}$ while the scan range was $41-450$ amu. The components were identified by comparing their retention times with the National Institute of Standards and Technology (NIST, ver. 2.0, 2008) mass spectral library database.

\section{Experimental animals}

A total of seventy-five (75) albino Wistar rats of both sexes and one rabbit sourced from the laboratory animal unit of Department of Veterinary Physiology and Pharmacology, Michael Okpara University of Agriculture, Umudike were used for the study. The animals were housed in wire-mesh rodent cages and had unrestricted access to pelleted rat feed (Vital Feed) and water except when fasting were required. They were fasted before the experiments; food $(16 \mathrm{~h})$ and water $(2 \mathrm{~h})$ prior to drug or ESE administration. The experimental protocol was approval by the Michael Okpara University of Agriculture,
Umudike Animal Use Ethics Committee, and all animals were humanely handled as stipulated in the Guide for the Care and Use of Laboratory Animals of National Research Council. (19).

\section{Experimental design \\ Indomethacin-induced gastric ulcer model}

The gastroprotective effects of ESE against indomethacininduced gastric ulcers were studied according to the method of Inas et al (23). Briefly, Wistar rats of both sexes $(n=25)$ were weighed and randomly assigned to five groups (A-E).

Group A: received distilled water $5.0 \mathrm{ml} / \mathrm{kg}$ (control)

Group B: received cimetidine $100 \mathrm{mg} / \mathrm{kg}$ (reference standard)

Group C: received ESE $25 \mathrm{mg} / \mathrm{kg}$

Group D: received ESE $50 \mathrm{mg} / \mathrm{kg}$

Group E: received ESE $100 \mathrm{mg} / \mathrm{kg}$

The doses used in this study were based on previous studies (18). All doses of ESE, cimetidine and distilled water were administered orally with the aid of a gastric gavage. One hour (1 h) post treatment, the rats were given indomethacin (Romacid ${ }^{\circledR}$ Jiangsu, China) (40 mg/kg body weight) per os. Four hours (4 h) post indomethacin administration the rats were sacrificed through cervical dislocation, and the stomachs were removed, cut open along greater curvature and were washed under slow running tap water. Ulcer lesions were counted with the aid of magnifying lenses ( $\times 10$ magnification), and scored on the basis of intensity as follow; $0=$ no ulcer, 1 = superficial ulcer, 2 = deep ulcers, 3 = perforations. Thereafter, ulcer index and percentage inhibition were calculated as follows:

Ulcer index $\left(\mathrm{U}_{\mathrm{I}}\right)=\left(\mathrm{U}_{\mathrm{N}}+\mathrm{U}_{\mathrm{S}}+\mathrm{U}_{\mathrm{P}}\right) \times 1 / 10$

Where, $\mathrm{U}_{\mathrm{N}}=$ average number of ulcer per animal, $\mathrm{U}_{\mathrm{S}}=$ average severity score, $U_{P}=$ percentage of animal with ulcer and $\mathrm{U}_{\mathrm{I}}=$ ulcer index. The percentage ulcer inhibition (PUI), was determined using the formula:

$$
\mathrm{PUI}=\frac{\mathrm{UI} \text { (control) }-\mathrm{UI}(\text { Treatment })}{\mathrm{UI}(\text { control) }} \times \frac{100}{1}
$$

\section{Ethanol-induced gastric ulcer}

The gastroprotective effect ESE against ethanol-induced ulcer model was studied according to the modified method of Silva et al. (24). Twenty five (25) Wistar rats were randomly assigned to five (A-E) groups $(n=5)$, as described in previous experiment, however, misoprostol (Zahidi Enterprise, India) $50 \mu \mathrm{g} / \mathrm{kg}$ body weight, was used as the reference drug. $1 \mathrm{~h}$ post treatment, all the animals were given $1 \mathrm{ml}$ of ethanol (Sigma Aldrich, Germany) via oral gavage. Two hours later all the animals were sacrificed through cervical dislocation, and their stomach were removed and cut open along the greater curvature. The ulcer lesions were observed as previously described, and UI and PUI, calculated as aforementioned under indomethacin-induced ulceration.

\section{Pyloric ligation method}

The modified method of Shay et al., (25) as presented in Sharma et al. (26) was adopted for this investigation with slight 
modifications. Adult Wistar rats were grouped into 5 groups (A-E, $n=5$ each) and food was removed for $48 \mathrm{~h}$, in a modified metal cage to discourage coprophagy. Groups A - E were orally treated with ESE and controls as previously mentioned under indomethacin-induced ulceration. Immediately after $1 \mathrm{~h}$ of oral treatments, the rats were anaesthetized by intraperitoneal administration of thiopentone sodium ( $30 \mathrm{mg} / \mathrm{kg}$ body weight). A laparotomy was carried out, and the pyloric sphincter loosely ligated to avoid occluding blood vessels. The stomach and abdominal contents were immediately sutured carefully in 2 layers of interrupted suture pattern using silk. They were placed in improvised recovery tubes (2-inch plastic pipe). The animals were starved of water post-operation. Sixteen hours post operation, each rat was sacrificed through cervical dislocation and eviscerated, the stomach exteriorized, and entire stomach content collected into a calibrated tube, to determine gastric juice volume, then centrifuged at $3000 \mathrm{rpm}$ for $5 \mathrm{~min}$ and the supernatant titrated against $0.1 \mathrm{M} \mathrm{NaOH}$ to determine acidity.

\section{Histopathologic examination}

Sample stomach tissues from test rats of indomethacininduced ulcer models were collected and fixed in 10\% formal saline. Thereafter, sectioned and hematoxylin and eosin $(\mathrm{H}$ $\&$ E)-stained stomach tissues were viewed under digital light microscope (10).

\section{Assessment of the effects of ESE on isolated rabbit jejunum ex vivo \\ The effect of ESE on intestinal smooth muscle contraction was evaluated using isolated rabbit jejunum with the aid of a physiograph as described by Ijioma et al (24). ESE was tested at final bath concentration in the ranges of $57-456 \mu \mathrm{g} / \mathrm{ml}$ in the absence and presence of acetylcholine $(0.029 \mu \mathrm{g} / \mathrm{ml})$ and histamine $(0.29 \mu \mathrm{g} / \mathrm{ml})$. The final bath concentration was determined using the formula below:}

Final bath concentration $(\mathrm{FBC})=$

$$
\frac{\text { test concentration } \times \text { volume used }}{\text { bath volume }}
$$

\section{Statistical analysis}

Data obtained were presented as mean \pm SEM and analysed using one-way analysis of variance (ANOVA) and post-hoc comparisons were carried out using either Dunnett's t-test or the Newman-Keuls test (where appropriate) on GraphPad Prism version 4.05 . Values of $P<0.05$ were considered significant in the study.

\section{Results}

\section{Chemical composition of ESE as identified by the GC-MS}

Six (6) compounds were identified during the GC-MS analysis of ESE. The GC-MS chromatogram shown 6 peaks (Fig. 1). The identified compounds are benzenesulfonyl chloride (40.63\%), benzopyran-4-one, 5,7-dihydroxy-2-phenyl- (21.25\%), benzenesulfonic acid, methyl ester (15.63\%), 2(5H)-furanone, 4-methoxy-5-phenyl- (12.50\%), 4,5-dimethylthiazole (4.38\%) and p-chlorobenzenesulfonyl chloride (5.63\%) (Table 1).

\section{Effects of ESE against indomethacin-induced ulcer}

Oral administration of the ESE $(25 \mathrm{mg} / \mathrm{kg})$ and cimetidine (100 $\mathrm{mg} / \mathrm{kg})$ produced significantly $(P<0.05)$ decreased ulcer score, ulcer severity and ulcer index in test rats compared with the control group (Table 2).

\section{Effects of ESE against ethanol-induced gastric ulcer}

All the doses of ESE $(25,50$ and $100 \mathrm{mg} / \mathrm{kg})$ and misoprostol $50 \mu \mathrm{g} / \mathrm{kg}$ produced significantly $(P<0.05)$ decreased ulcer index compared with distilled water treated rats (control). The inhibition of ulcer index in treated groups did not show dosedependent effect (Table 2). Although, the standard reference, misoprostol significantly $(P<0.05)$ decreased the ulcer score

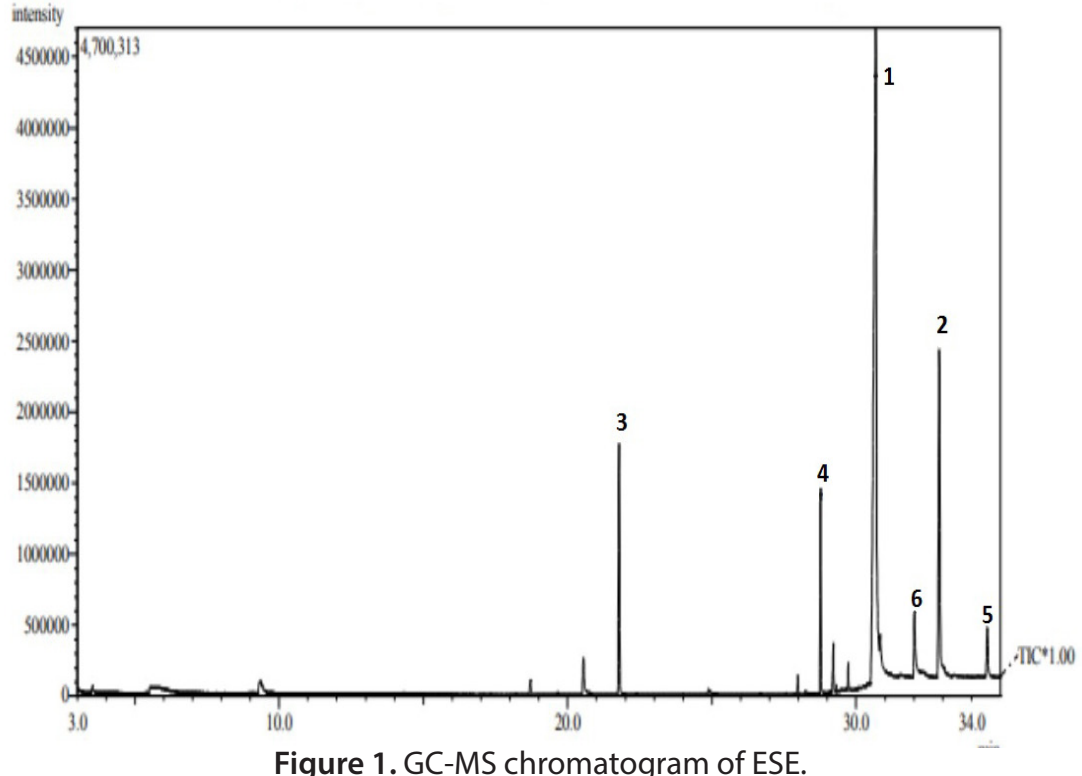

1 = benzenesulfonyl chloride, 2 = benzopyran-4-one, 5,7-dihydroxy-2-phenyl-, $\mathbf{3}$ = benzenesulfonic acid, methyl ester, $4=2$ (5H)furanone, 4-methoxy-5-phenyl-, $5=4,5$-dimethylthiazole, 6 = p-chlorobenzenesulfonyl chloride. 
Table 1. Chemical composition of ESE as identified by the GC-MS

\begin{tabular}{cccccc}
$\mathrm{S} / \mathrm{N}$ & $\mathrm{RT}(\mathrm{min})$ & $\%$ & $\mathrm{MW}(\mathrm{g})$ & $\mathrm{MF}$ & Chemical name \\
\hline 1 & 30.60 & 40.63 & 176 & $\mathrm{C}_{6} \mathrm{H}_{5} \mathrm{ClO}_{2} \mathrm{~S}$ & Benzenesulfonyl chloride \\
2 & 33.00 & 21.25 & 254 & $\mathrm{C}_{15} \mathrm{H}_{10} \mathrm{O}_{4}$ & Benzopyran-4-one, 5,7-dihydroxy-2-phenyl- \\
3 & 21.80 & 15.63 & 172 & $\mathrm{C}_{7} \mathrm{H}_{8} \mathrm{O}_{3} \mathrm{~S}$ & Benzenesulfonic acid, methyl ester \\
4 & 28.80 & 12.50 & 190 & $\mathrm{C}_{11} \mathrm{H}_{10} \mathrm{O}_{3}$ & 2 2(5H)-Furanone, 4-methoxy-5-phenyl- \\
5 & 34.50 & 4.38 & 113 & $\mathrm{C}_{5} \mathrm{H}_{7} \mathrm{NS}_{6}$ & 4,5-Dimethylthiazole \\
6 & 32.00 & 5.63 & 210 & $\mathrm{C}_{6} \mathrm{H}_{4} \mathrm{Cl}_{2} \mathrm{O}_{2} \mathrm{~S}$ & p-Chlorobenzenesulfonyl chloride \\
RT = retention time, \% = percentage composition, $\mathrm{MW}=$ molecular weight, $\mathrm{MF}$ = molecular formula
\end{tabular}

Table 2. Effects of ESE against indomethacin-induced gastric ulcer

\begin{tabular}{lcccc} 
Group & Ulcer score & Ulcer severity & Ulcer index & \% inhibition \\
\hline Distilled water, $5 \mathrm{ml} / \mathrm{kg}$ & $9.80 \pm 1.46$ & $16.00 \pm 0.84$ & $12.58 \pm 0.07$ & - \\
Cimetidine, $100 \mathrm{mg} / \mathrm{kg}$ & $5.80 \pm 1.11^{*}$ & $10.80 \pm 2.82$ & $11.66 \pm 0.32^{*}$ & 7.31 \\
$\mathrm{ESE}, 25 \mathrm{mg} / \mathrm{kg}$ & $4.00 \pm 0.82^{*}$ & $6.50 \pm 1.55^{*}$ & $11.05 \pm 0.18^{*}$ & 12.16 \\
$\mathrm{ESE}, 50 \mathrm{mg} / \mathrm{kg}$ & $8.50 \pm 1.20$ & $14.25 \pm 1.80$ & $12.28 \pm 0.29$ & 2.38 \\
$\mathrm{ESE}, 100 \mathrm{mg} / \mathrm{kg}$ & $8.00 \pm 2.31$ & $15.67 \pm 5.93$ & $12.37 \pm 0.58$ & 1.67 \\
${ }^{*} \mathrm{p}<0.05 \mathrm{compared}$ with distilled water treated rats, ESE = Eremomastax speciosa extract & & & \\
\hline
\end{tabular}

Table 3. Effects of ESE on ethanol-induced ulcer

$\begin{array}{lcccc}\text { Group } & \text { Ulcer score } & \text { Ulcer severity } & \text { Ulcer index } & \text { \% inhibition } \\ \text { Distilled water, } 5 \mathrm{ml} / \mathrm{kg} & 8.33 \pm 1.65 & 17.33 \pm 3.94 & 12.57 \pm 0.55 & - \\ \text { Misoprostol, } 50 \mu \mathrm{g} / \mathrm{kg} & 0.50 \pm 0.29 * & 1.00 \pm 0.71^{*} & 5.15 \pm 0.07^{*} & 59.03 \\ \mathrm{ESE}, 25 \mathrm{mg} / \mathrm{kg} & 3.75 \pm 2.25 & 9.00 \pm 5.93 & 6.28 \pm 0.63^{*} & 50.04 \\ \mathrm{ESE}, 50 \mathrm{mg} / \mathrm{kg} & 7.67 \pm 1.17 & 17.67 \pm 3.15 & 8.53 \pm 0.40^{*} & 32.14 \\ \mathrm{ESE}, 100 \mathrm{mg} / \mathrm{kg} & 5.00 \pm 2.41 & 8.40 \pm 3.61 & 7.34 \pm 0.49 * & 41.61 \\ { }^{*} \mathrm{p}<0.05 \mathrm{compared} \text { with distilled water treated rats, ESE = Eremomastax speciosa extract } & & & \end{array}$

Table 4. Effect of ESE on total gastric acidity

\begin{tabular}{lcc} 
Group & Total gastric acidity (mole/L) & \% reduction \\
\hline Distilled water, $5 \mathrm{ml} / \mathrm{kg}$ & $0.08 \pm 0.00$ & - \\
Cimetidine, $100 \mathrm{mg} / \mathrm{kg}$ & $0.03 \pm 0.01^{*}$ & 62.5 \\
$\mathrm{ESE}, 25 \mathrm{mg} / \mathrm{kg}$ & $0.06 \pm 0.00$ & 50 \\
$\mathrm{ESE}, 50 \mathrm{mg} / \mathrm{kg}$ & $0.04 \pm 0.01^{*}$ & 12.5 \\
$\mathrm{ESE}, 100 \mathrm{mg} / \mathrm{kg}$ & $0.07 \pm 0.01$ & 25 \\
${ }^{*} \mathrm{p}<0.05$ when compared with distilled water treated group, ESE $=$ Eremomastax speciosa extract & \\
\hline
\end{tabular}


and severity, the extract at all doses did not show any significant ( $p>0.05)$ decrease in ulcer score or severity (Table 3 ).

\section{Effect of ESE on total gastric acidity}

The extract, ESE $(50 \mathrm{mg} / \mathrm{kg})$ elicited significantly $(P<0.05)$ decreased total gastric acidity, while ESE 25 and $100 \mathrm{mg} / \mathrm{kg}$ as well as cimetidine $(100 \mathrm{mg} / \mathrm{kg})$, produced no significant $(P$ $>0.05)$ reduction in total gastric acidity compared with the control group. The highest dose of ESE $(100 \mathrm{mg} / \mathrm{kg})$ used in the study produced comparable percentage reduction in total gastric acidity (Table 4 ).

\section{Histopathologic examination}

Fig. 2 (A-E) show representative photomicrographs of the histopathological sections of stomach from indomethacininduced gastric ulcers of groups A to E. These sections of the stomach indicate the severity of the ulcers (indicated using arrows). The distilled water treated (A), and ESE (100 mg/kg; E) showed increased numbers as well as deeper gastric ulcerations when compared to cimetidine (100 mg/kg; B) or ESE (25 and $50 \mathrm{mg} / \mathrm{kg}$; C and D respectively) treated groups (Fig. 2).

\section{Effect of ESE on isolated rabbit jejunum}

All concentrations of ESE $(57-456 \mu \mathrm{g} / \mathrm{mL})$ used in this study produced a concentration-dependent relaxation of the intrinsic contraction of the isolated rabbit jejunum (Fig. 3). ESE also caused inhibition of both acetylcholine- and histamineinduced increase in intrinsic contraction of isolated jejunum (Figs. 4-6).

\section{Discussion}

This study evaluated the gastroprotective effects of the methanol extract of Eremomastax speciosa leaf on experimentally induced ulcers in rats. The E. speciosa extracts (ESE) produced gastroprotective effects in the ulcer models tested as well as elicited anticholinergic and antihistaminic activities. The GC-MS analysis of ESE identified six bioactive compounds. The gastroprotective activities of E. speciosa was attributed to the presence of benzopyran-4-one, 5,7-dihydroxy-2-phenyl(chrysin).

Prostaglandin stimulates increased bicarbonate and mucus synthesis and enhance mucosal blood flow, hence, maintaining mucosal repair and integrity of the mucosa (25). Suppressed
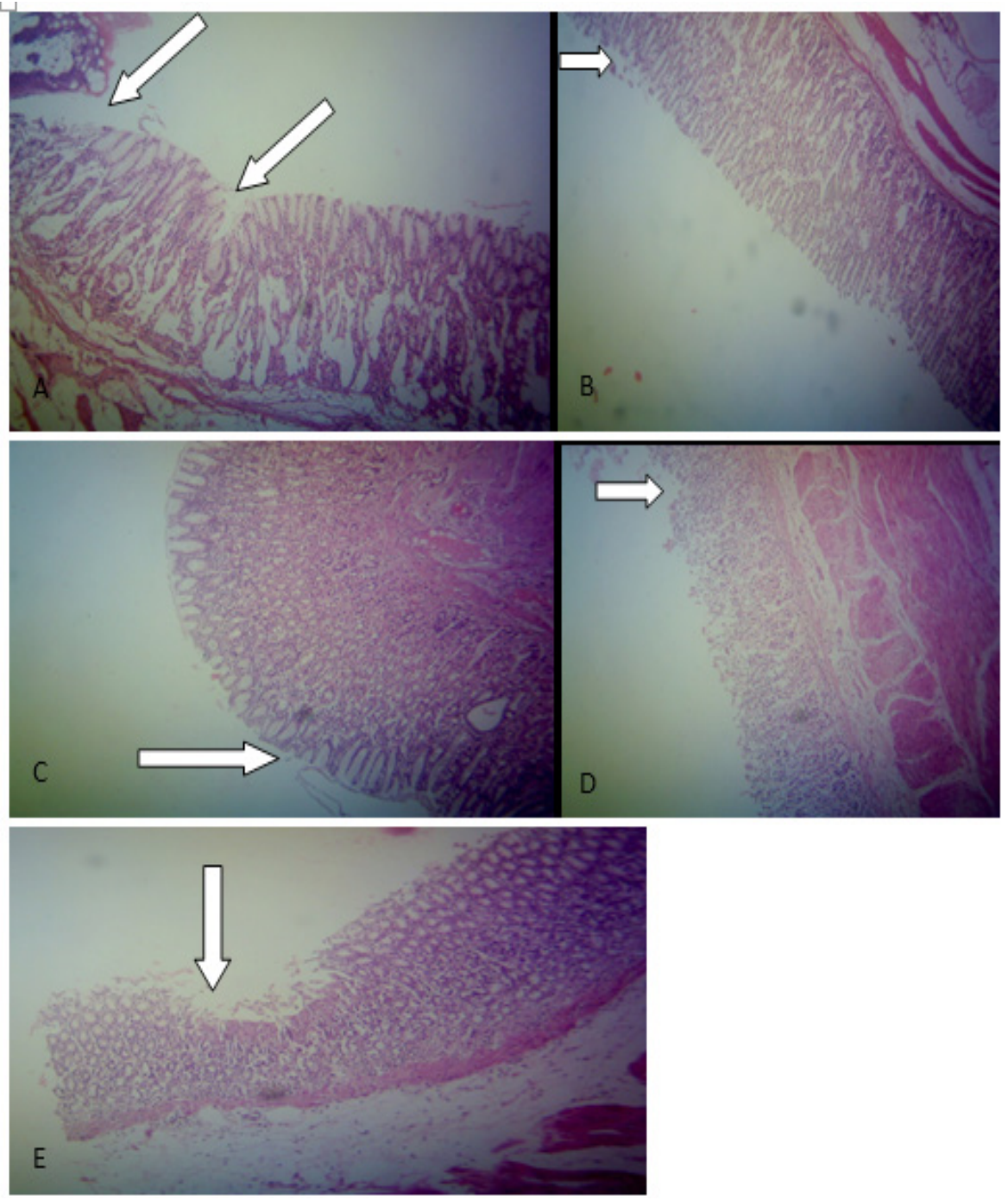

Figure 2. Stomach sections of effects of ESE against indomethacin-induced gastric ulcer.

Arrows indicate points of gastric ulceration. Plates A- E represents various treatments; groups A = distilled water $5.0 \mathrm{ml} / \mathrm{kg}$, $\mathrm{B}=$ cimetidine $100 \mathrm{mg} / \mathrm{kg}, \mathrm{C}=\mathrm{ESE} 25 \mathrm{mg} / \mathrm{kg}, \mathrm{D}=\mathrm{ESE} 50 \mathrm{mg} / \mathrm{kg}, \mathrm{E}=\mathrm{ESE} 100 \mathrm{mg} / \mathrm{kg}$ (x 100 magnification). 


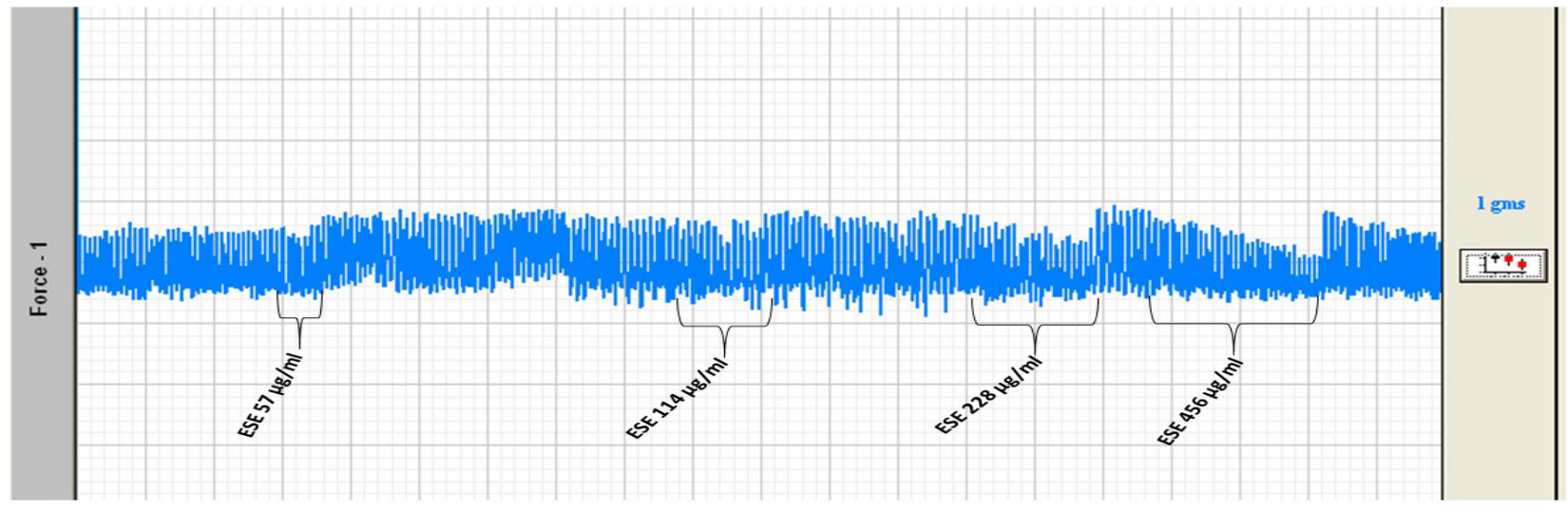

Figure 3. The relaxant effects of ESE on isolated rabbit jejunum ex vivo.

$\mathrm{ESE}=$ Eremomastax specios $a$ extract, final bath concentration of ESE ranged between $57-456 \mu \mathrm{g} / \mathrm{mL}$.

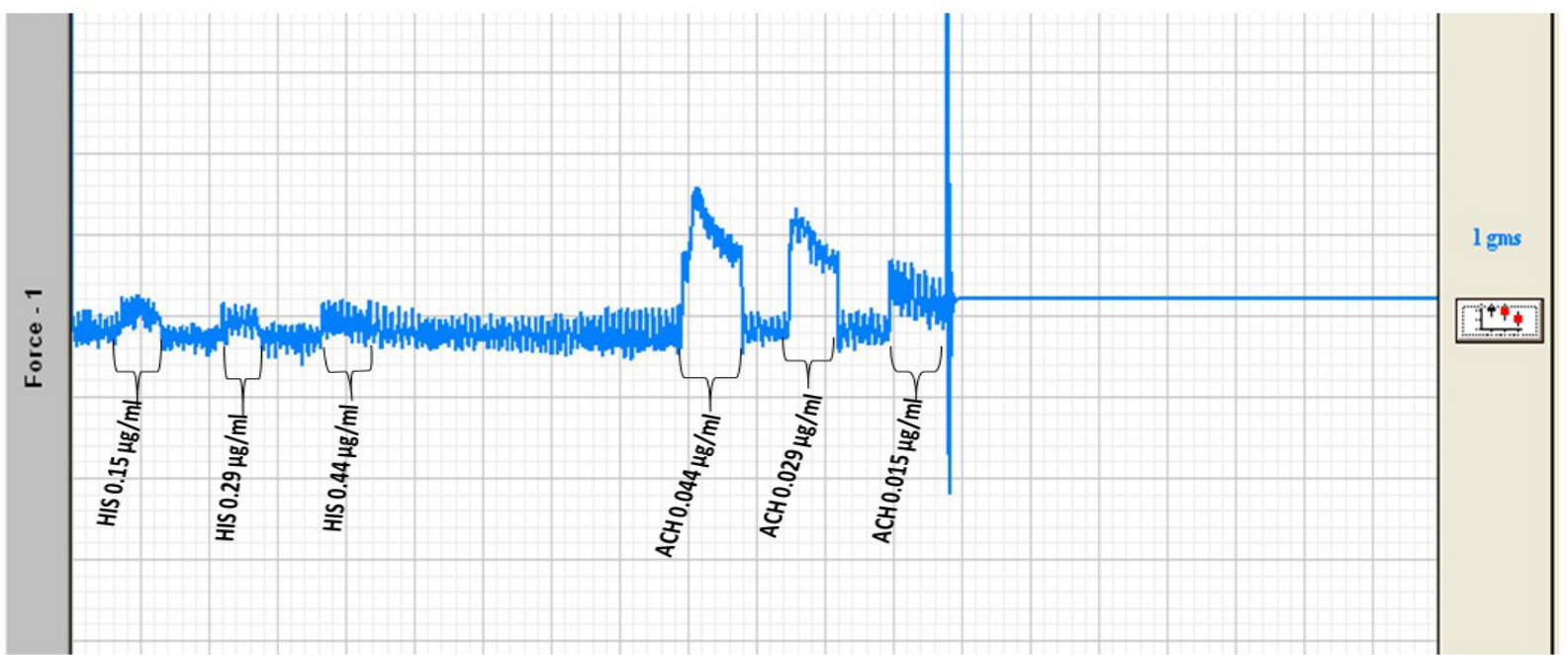

Figure 4. Concentration-dependent effects of histamine and acetylcholine on the intrinsic contraction in isolated rabbit jejunum ex vivo. $\mathrm{HIS}=$ histamine, $\mathrm{ACH}=$ acetylcholine, the final bath concentration of histamine was between $0.15-0.44 \mu \mathrm{g} / \mathrm{mL}$ while the final bath concentration of acetylcholine was between $0.015-0.044 \mu \mathrm{g} / \mathrm{ml}$.

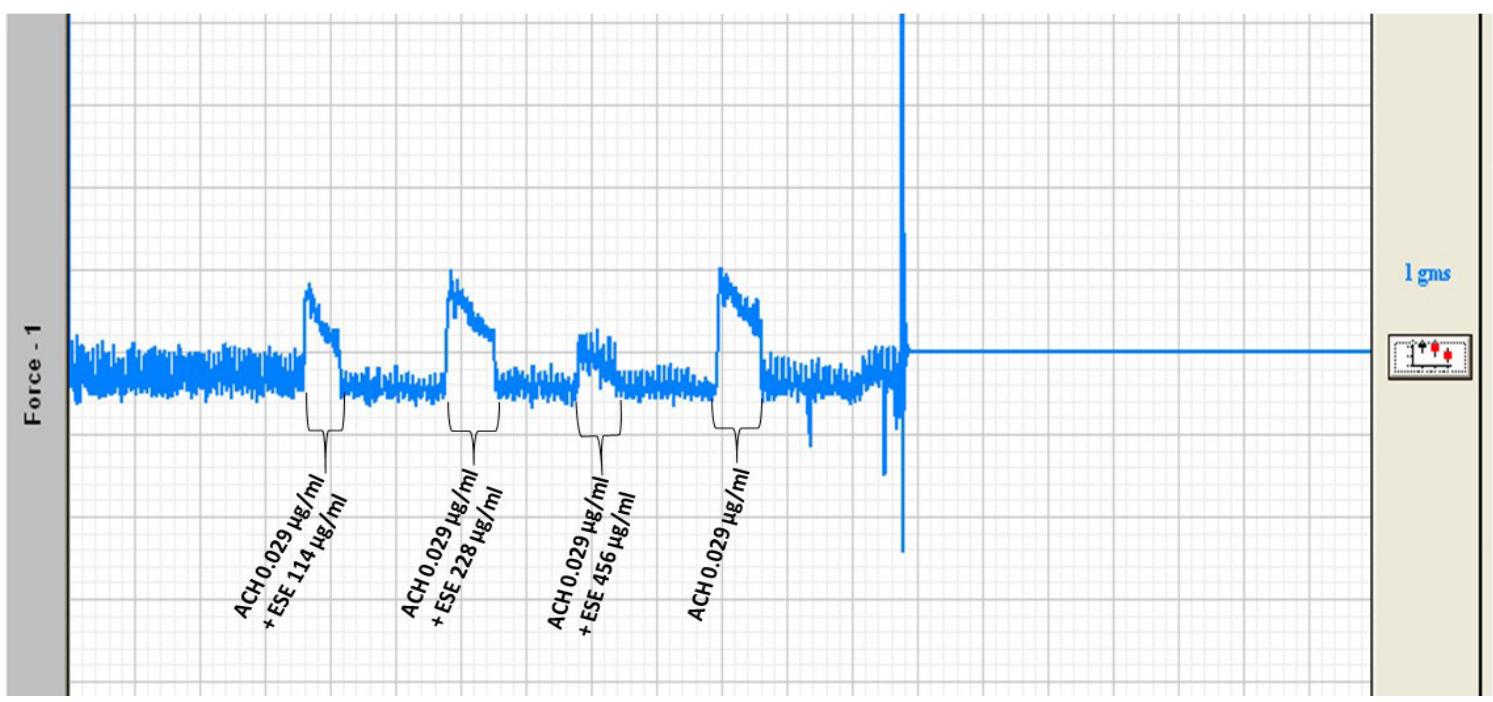

Figure 5. The inhibitory effects of ESE on acetylcholine-induced increased intrinsic contraction of isolated rabbit jejunum ex vivo. $\mathrm{ACH}=$ acetylcholine, $\mathrm{ESE}=$ Eremomastax speciosa extract, the final bath concentration of acetylcholine was $0.029 \mu \mathrm{g} / \mathrm{mL}$ while the final bath concentration of ESE ranged between $114-456 \mu \mathrm{g} / \mathrm{mL}$. 


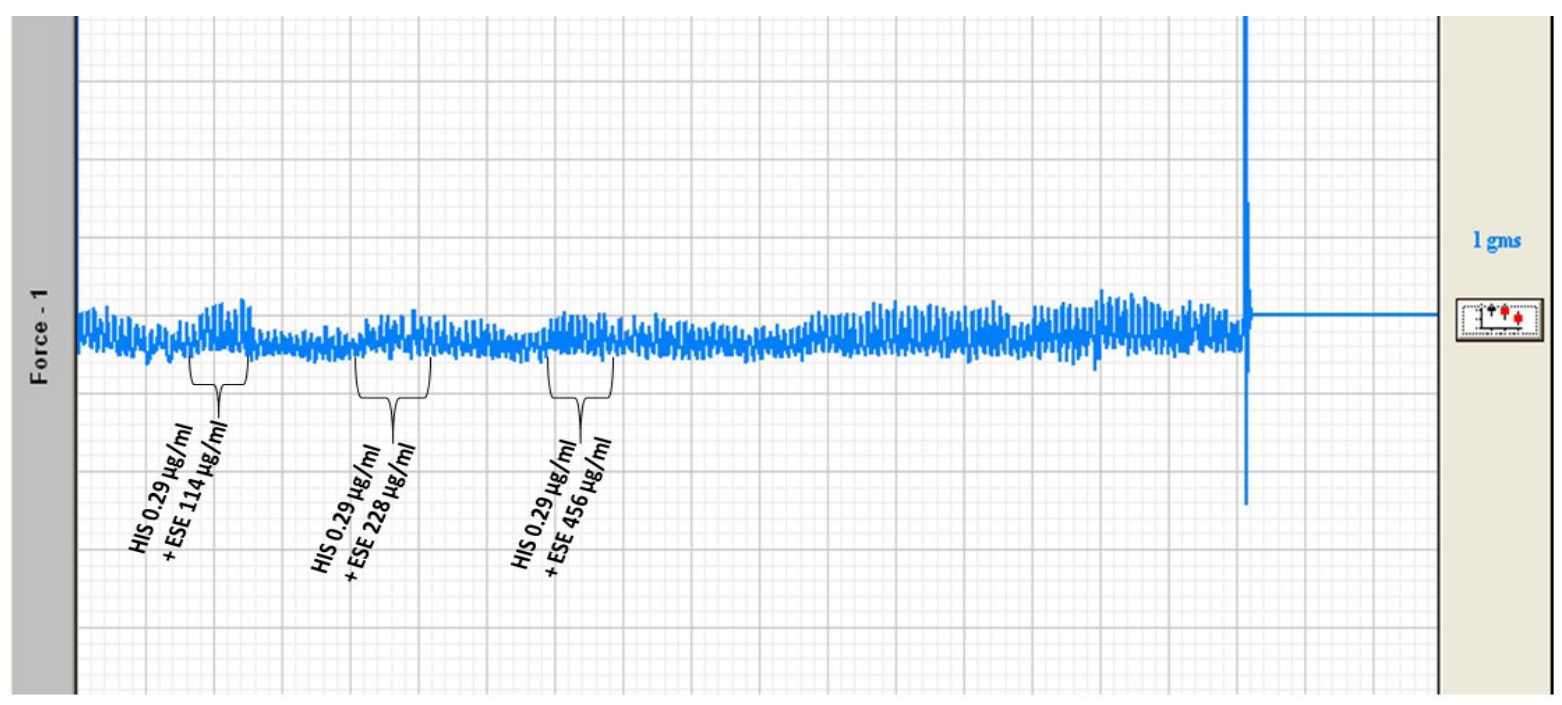

Figure 6. The inhibitory effects of ESE on histamine-induced increased intrinsic contraction of isolated rabbit jejunum ex vivo. $\mathrm{HIS}=$ histamine, ESE = Eremomastax speciosa extract, the final bath concentration of histamine was $0.29 \mu \mathrm{g} / \mathrm{mL}$ while the final bath concentration of ESE ranged between $114-456 \mu \mathrm{g} / \mathrm{mL}$.

prostaglandins and elevated free radical levels predispose to stomach mucosal injury and duodenal ulceration $(26,27)$. Indomethacin and ethanol induces gastric ulcers via the inhibition of COX, a pivotal enzyme for prostaglandin biosynthesis from arachidonic acid as well as the formation of free radicals $(5,20,27-29)$. Antioxidants prevent oxidative damage of cell membranes and enhance ulcer wound healing (30). The anti-ulcer activities of ESE could be akin to enhanced prostaglandin synthesis and its antioxidant activity $(11,18)$. We previously associated, as a probable mechanism of anti-nociception effects of E. speciosa, to the inhibition of cyclooxygenase required to catalyze the synthesis of prostaglandins (18). Other researchers have previously reported on the anti-ulcer and anti-nociceptive activities of Melastoma malabathricum, Maytenus ilicifolia and Piper aleyreanum) (31-33). Our findings are corroborated in earlier reports on the antiulcer activities of Barleria gibsoni and Terminalia chebula fruit $(23,30)$.

The percentage ulcer inhibition of extract $(25 \mathrm{mg} / \mathrm{kg})$ was comparable to misoprostol $(50 \mu \mathrm{g} / \mathrm{kg})$ in the ethanol-induced ulcer model. Misoprostol is a prostaglandin analogue that stimulate mucus and bicarbonate production, inhibit gastric acid secretion and cause vasodilation which shield the stomach mucosa against damage (34). This suggests that both ESE and misoprostol conferred cytoprotective effect on gastric mucosa and could be the possible mechanism of action. The mucusbicarbonate layer create a near neutral microenvironment $(\mathrm{pH} 7)$ at the mucus-mucosa interface and also prevent the proteolytic digestion of gastric epithelium by pepsin (35). It was observed that ESE caused dose-dependent increase in the gastric mucus content in the shay rat and ethanol-induced ulcer models, similar to the reference drug (the volume was not quantified; thus data not shown). The increased mucus content suggests that the extract might have influenced the release of chemical mediators that regulate the formation of gastric mucus such as gastrin, secretin, prostaglandin and acetylcholine (36).

The inhibition of cholinergic and histaminic effects by the extracts may be responsible for the decrease in total gastric contents (36). ESE not only relaxed the jejunum, but also exhibited a concentration-dependent decrease in the magnitude of acetylcholine- and histamine-induced contraction of isolated rabbit jejunum, thus suggesting that ESE possesses anticholinergic and antihistaminic properties (34). The anticholinergic and antihistaminic activities of ESE is in agreement with the report of André Perfusion et al (12). Gastric acid secretion is positively regulated by acetylcholine and histamine receptors in the gastric parietal cell, stimulating the proton pump to release hydrogen $\left(\mathrm{H}^{+}\right)$ ion with concomitant increase in gastric acid content $(34,36)$, hence the observed decrease in gastric acidity following ESE administration.

The demonstrated gastroprotective potential of E. speciosa could be attributed to the presence of Benzopyran-4-one, 5,7-dihydroxy-2-phenyl- (chrysin derivative). Babu et al (37) reported the gastroprotective effects of chrysin and its derivative isolated from Oroxylum indicum against pyloric ligation, cold-restrain, ethanol and aspirin induced ulceration models in rats. The findings of this study corroborated the previous reports on the antisecretory and antiulcer activities of E. speciosa leaf harvested from Yaounde, Cameroun (11, 12, $38,39)$. They differed only in the effective doses of the extracts which could be attributed to the difference in phytochemical composition. The potency of medicinal plants depend on the content and composition of the secondary metabolites such as: saponins, tannins, flavonoids, terpenes, sterols, glycoside and alkaloids which are dependent on climatic factor, soil condition and stage of vegetative growth of the plant at the time of collection (40). 


\section{Conclusion}

The finding studies demonstrated that methanol extract of Eremomastax speciosa possess potent gastroprotective effects which may be mediated through anticholinergic and antihistaminic mechanisms. This study provide the pharmacological background for the ethnomedicinal use of $E$. speciosa leaf decoction in the treatment of stomach ulcer by the natives.

\author{
Abbreviations \\ $\mathrm{ESE}=$ Eremomastax speciosa extract \\ $\mathrm{HIS}=$ histamine \\ $\mathrm{ACH}=$ acetylcholine \\ GC-MS = Gas chromatography-mass spectroscopy
}

\section{Acknowledgement}

We are grateful to Mr. Okon Etefia for plant identification.

\section{Conflict of interest statement}

The authors declare that they have no conflict of interest.

\section{References}

1. Sahoo SK, Sahoo HB, Priyadarshini D, Soundarya G, Rani KU. Antiulcer Activity of Ethanolic Extract of Salvadora indica ( W .) Leaves on Albino Rats. J Clin Diagnostic Res 2016; 10(9): 7-10.

2. Zakaria ZA, Balan T, Suppaiah V, Ahmad S, Jamaludin F. Mechanism(s) of action involved in the gastroprotective activity of Muntingia calabura. J Ethnopharmacol 2014; 151(3): 1184-1193.

3. Balan T, Mohd. Sani MH, Suppaiah V, Mohtarrudin N, Suhaili Z, Ahmad Z, et al. Antiulcer activity of Muntingia calabura leaves involves the modulation of endogenous nitric oxide and nonprotein sulfhydryl compounds. Pharm Biol 2014; 52(4): 410418.

4. Boligon AA, de Freitas RB, de Brum TF, Waczuk EP, Klimaczewski CV, de Ávila DS, et al. Antiulcerogenic activity of Scutia buxifolia on gastric ulcers induced by ethanol in rats. Acta Pharm Sin B 2014; 4(5): 358-367.

5. Dubois RN, Abramson SB, Crofford L, Gupta RA, Simon LS, Van De Putte LBA, et al. Cyclooxygenase in biology and disease. FASEB J 1998; 12(12): 1063-1073.

6. Miller TA. Protective effects of prostaglandins against gastric mucosal damage: current knowledge and proposed mechanisms. Am J Physiol Liver Physiol 1983; 245(5): G601-G623.

7. Miller TA. Mechanisms of stree-related mucosal damage. Am J Med 1987.

8. Robert A. Cytoprotection by Prostaglandins. Gastroenterology 1979; 77: 761-767.

9. Wallace JL, Keenan CM, Granger DN. Gastric ulceration induced by nonsteroidal anti-inflammatory drugs is a neutrophil-dependent process. Am J Physiol Liver Physiol 1990; 259(3): G462-G467.

10. Pradeepkumar B, Bhavyamadhuri CP, Padmanabhareddy $\mathrm{Y}$, Veerabhadrappa K V., Narayana G, Haranath C, et al. Evaluation of antiulcer activity of Peltophorum pterocarpum. J Clin Diagnostic Res 2017; 11(6): FF01-FF03.

11. Amang PA, Tan P V, Patamaken SA, Mefe MN. Cytoprotective and antioxidant effects of the methanol extract of Eremomastax speciosa in rats. African J Tradit Complement Altern Med 2014; 11(1): 165-171.

12. André Perfusion A, Tan $P$, Ernestine $N$, Barthélemy $N$. Antisecretory action of the extract of the aerial parts of Eremomastax speciosa (Acanthaceae) occurs through antihistaminic and anticholinergic pathways. Adv Pharmacol Sci
2014; 2014. doi:10.1155/2014/323470.

13. Idu EJO, Udo FO. Ethnomedicinal Survey of Medicinal Plants Used in the Treatment of Male Infertilty among the IFA Nkari People of Ini Local Government Area of. Res J Recent Sci 2013; 2(ISC-2012): 5-11.

14. Udofia Sl, Owoh PW, Ukpong EE, Ekpo IE. Assessment of plant species of socio- economic importance conserved in homegardens of Nsit Ubium local government area of Akwa lbom State, Nigeria. Niger J Agric Food Environ 2012; 8(1): 99-108.

15. Sagnia B, Fedeli D, Casetti R, Montesano C, Falcioni G, Colizzi V. Antioxidant and anti-inflammatory activities of extracts from Cassia alata, Eleusine indica, Eremomastax speciosa, Carica papaya and Polyscias fulva medicinal plants collected in Cameroon. PLoS One 2014; 9(8): e103999.

16. Okokon JE, Antia BS, Udoh AE, Akpan MM. Antianaemic and antimicrobial activity of Eremomastax speciosa. J Pharmacol Toxicol 2007; 2: 196-199.

17. Oben JE, Assi SE, Agbor GA, Musoro DF. Effect of Eremomastax speciosa on experimental diarrhoea. African J Tradit Complement Altern Med 2006; 3(1): 95-100.

18. Onoja SO, Eke C, Ejiofor E, Madubuike KG, Ezeja MI, Omeh YN, et al. antioxidant, anti-inflammatory and anti-nociceptive properties of hydro-methanol extract of Eremomastax speciosa (HOCHST.) CUFOD leaf. African J Tradit Complement Altern Med 2017; 14(6): 56-63.

19. National Research Council. Guide for the care and use of laboratory animals. National Academies Press; 2010, http://www. nap.edu/catalog/12910.html

20. Inas AZA, Hala KAH, Heeba HG. Gastroprotective effect of Cordia Myxa L. fruit extract against indomethacin-induced gastric ulceration in rats. Life Sci J 2011; 8(3): 433-445.

21. Silva LP, De Angelis CD, Bonamin F, Kushima $H$, Jose MF, Dos Santos LC, et al. Terminalia catappa L.: A medicinal plant from the Caribbean pharmacopeia with anti-Helicobacter pylori and antiulcer action in experimental rodent models. J Ethnopharmacol 2015; 159: 285-295.

22. Shay H, Komarov S, Fels S, Meranze D, Gruenstein M, Siplet H. A simple method for the uniform production of gastric ulceration in rat. Gastroenterology 1945; 5: 43-61.

23. Sharma P, Prakash T, Kotresha D, Ansari MA, Sahrm UR, Kumar B, et al. Antiulcerogenic activity of Terminalia chebula fruit in experimentally induced ulcer in rats. Pharm Biol 2011; 49(3): 262268.

24. Ijioma SN, Nwosu CO, Onyenegecha C. Anticholinergic property of ethanol extract of Moringa oleifera Leaves: An in vivo and in vitro approach. J Clin Exp Res 2014; 2(2): 133-137.

25. Hiruma-Lima CA, Calvo TR, Rodrigues CM, Andrade FDP, Vilegas W, Brito ARMS. Antiulcerogenic activity of Alchornea castaneaefolia: effects on somatostatin, gastrin and prostaglandin. J Ethnopharmacol 2006; 104(1): 215-224.

26. Al Batran R, Al-Bayaty F, Jamil Al-Obaidi MM, Abdualkader AM, Hadi HA, Ali HM, et al. In Vivo Antioxidant and Antiulcer Activity of Parkia speciosa Ethanolic Leaf Extract against Ethanol-Induced Gastric Ulcer in Rats. PLoS One 2013; 8(5): 2-12.

27. Yang X, Zhang X, Yang SP, Le T, Chen B. Evaluation of Aucklandia lappa Decne extracts as antiulcer activity in animals. Pak J Pharm Sci 2016; 29(5): 1695-1701.

28. Sabiu S, Garuba T, Sunmonu TO, Sulyman AO, Ismail NO. Indomethacin-induced gastric ulceration in rats: Ameliorative roles of Spondias mombin and Ficus exasperata. Toxicol Reports 2015; 2(0): 261-267.

29. Shokunbi OS, Odetola AA. Gastroprotective and antioxidant activities of Phyllanthus amarus extracts on absolute ethanolinduced ulcer in albino rats. J Med Plants Res 2015; 2(10): 261-267.

30. Tamboli F, More H. Evaluation of antiulcer and antioxidant activity 
of Barleria gibsoni Dalz. leaves. Pharmacognosy Res 2016; 8(4): 226.

31. Zabidi Z, Wan Zainulddin WN, Mamat SS, Shamsahal Din S, Kamisan FH, Yahya F, et al. Antiulcer activity of methanol extract of Melastoma malabathricum leaves in rats. Med Princ Pract 2012; 21(5): 501-503.

32. Jorge RM, Leite JP V, Oliveira AB, Tagliati CA. Evaluation of antinociceptive, anti-inflammatory and antiulcerogenic activities of Maytenus ilicifolia. J Ethnopharmacol 2004; 94(1): 93-100.

33. Lima DKS, Ballico LJ, Lapa FR, Gonçalves HP, de Souza LM, Iacomini $M$, et al. Evaluation of the antinociceptive, anti-inflammatory and gastric antiulcer activities of the essential oil from Piper aleyreanum C. DC in rodents. J Ethnopharmacol 2012; 142(1): 274282.

34. Rang HP, Dale MM, Ritter JM, Moore PK. Pharmacology (5th edn). Churchill Livingstone: Edinburgh 2007.

35. Allen A, Flemström G. Gastroduodenal mucus bicarbonate barrier: protection against acid and pepsin. Am J Physiol Physiol 2005; 288(1): C1-C19.

36. Schubert ML, Peura DA. Control of gastric acid secretion in health and disease. Gastroenterology 2008; 134(7): 1842-1860.

37. Babu HT, Manjulatha K, Kumar SG, Hymavathi A, Tiwari AK, Purohit $\mathrm{M}$, et al. Gastroprotective flavonoid constituents from Oroxylum indicum Vent. Bioorganic Med Chem Lett 2010; 20(1): 117-120.

38. Amang AP, Mezui C, Siwe GT, Emakoua J, Mbah G, Nkwengoua $E Z$, et al. Healing and antisecretory effects of aqueous extract of Eremomastax speciosa (Acanthaceae) on unhealed gastric ulcers. Biomed Res Int 2017. https://doi.org/10.1155/2017/1924320

39. Tan PV, Nditafon NG, Yewah MP, Dimo T, Ayafor FJ. Eremomastax speciosa: effects of leaf aqueous extract on ulcer formation and gastric secretion in rats. J Ethnopharmacol 1996; 54: 139-142.

40. Sofowora EA. Medicinal plants and traditional medicine in Africa. 3rd ed. Spectrum books Ltd: Nigeria 2008. 